NBER WORKING PAPER SERIES

\title{
WHO OWNS THE WEALTH IN TAX HAVENS? MACRO EVIDENCE AND IMPLICATIONS FOR GLOBAL INEQUALITY
}

\author{
Annette Alstadsæter \\ Niels Johannesen \\ Gabriel Zucman \\ Working Paper 23805 \\ http://www.nber.org/papers/w23805 \\ NATIONAL BUREAU OF ECONOMIC RESEARCH \\ 1050 Massachusetts Avenue \\ Cambridge, MA 02138 \\ September 2017
}

We are grateful for financial support from the Nordic Tax Research Council and the FRIPROprogram of the Research Council of Norway. Johannesen gratefully acknowledges financial support from the Danish Council for Independent Research. Zucman gratefully acknowledges financial support from the Laura and John Arnold Foundation. The views expressed herein are those of the authors and do not necessarily reflect the views of the National Bureau of Economic Research.

NBER working papers are circulated for discussion and comment purposes. They have not been peer-reviewed or been subject to the review by the NBER Board of Directors that accompanies official NBER publications.

(C) 2017 by Annette Alstadsæter, Niels Johannesen, and Gabriel Zucman. All rights reserved. Short sections of text, not to exceed two paragraphs, may be quoted without explicit permission provided that full credit, including $(\odot)$ notice, is given to the source. 
Who Owns the Wealth in Tax Havens? Macro Evidence and Implications for Global Inequality Annette Alstadsæter, Niels Johannesen, and Gabriel Zucman

NBER Working Paper No. 23805

September 2017

JEL No. E21,H26,H87

\begin{abstract}
$\underline{\text { ABSTRACT }}$
Drawing on newly published macroeconomic statistics, this paper estimates the amount of household wealth owned by each country in offshore tax havens. The equivalent of $10 \%$ of world GDP is held in tax havens globally, but this average masks a great deal of heterogeneity-from a few percent of GDP in Scandinavia, to about 15\% in Continental Europe, and 60\% in Gulf countries and some Latin American economies. We use these estimates to construct revised series of top wealth shares in ten countries, which account for close to half of world GDP. Because offshore wealth is very concentrated at the top, accounting for it increases the top $0.01 \%$ wealth share substantially in Europe, even in countries that do not use tax havens extensively. It has considerable effects in Russia, where the vast majority of wealth at the top is held offshore. These results highlight the importance of looking beyond tax and survey data to study wealth accumulation among the very rich in a globalized world.

Annette Alstadsæter

Norwegian University of Life Sciences

annette.alstadsater@nmbu.no

Niels Johannesen

University of Copenhagen

Department of Economics

and CEBI

niels.johannesen@econ.ku.dk

Gabriel Zucman

Department of Economics

University of California, Berkeley

530 Evans Hall, \#3880

Berkeley, CA 94720

and NBER

zucman@berkeley.edu
\end{abstract}




\section{Introduction}

Measuring the wealth of rich households is getting increasingly hard in a globalized world. Since the 1980s, a large offshore wealth management industry has developed in Switzerland, Hong Kong, the Bahamas, and similar offshore financial centers. Banks located in these countries cater to wealthy individuals from around the world. They provide a variety of financial services to these individuals, many of which are legal and legitimate, but most of which make wealth harder to observe in traditional economic datasets, such as national accounts and tax records. Zucman (2013) estimates that $8 \%$ of the world's household financial wealth - the equivalent of $10 \%$ of world GDP - is held offshore. There is evidence that global offshore wealth has increased considerably over the last four decades, as a growing number of offshore centers have entered the market for cross-border wealth management, and information technology and financial innovation have made it simpler to move funds oversees.

Yet the implications of the globalization of wealth management are not well understood. As offshore centers rarely publish informative statistics, we do not have a clear view of who uses tax havens. Does most of the wealth held offshore belong to residents of rich countries, or to residents of developing countries? Does it mostly belong to ultra-rich households (e.g., with more than $\$ 50$ million in net wealth), to corrupt political elites, or to a broader segment of the population? Is most of it hidden from tax authorities, or do people use tax havens for non-tax reasons - for instance, to get access to better financial services than available in their home country? These are key issues for the study of inequality, public economics, and developmentand likely to become even more important in the future, as global wealth is rising fast and increasingly takes the form of movable financial assets (Piketty and Zucman, 2014).

In this paper, we take a step toward addressing these questions by drawing on newly published macroeconomic statistics. In 2016, a number of prominent offshore financial centersincluding Switzerland, Luxembourg, the Channel Islands, and Hong Kong - started disclosing bilateral data on the amount of bank deposits that foreigners own in their banks. These data have been collected for several decades by the Bank for International Settlements (BIS), but until 2016 the BIS only disclosed statistics aggregated at the country level (such as the total amount of foreign-owned bank deposits in Hong Kong) rather than at the bilateral level (such as the amount of bank deposits owned by Indian residents in Hong Kong). In 2016, most offshore centers authorized the BIS to disseminate bilateral data. These series are retrospective and go back in most cases to the early 2000s, or even earlier. As a result, we now have access to time

series for the value of the bank deposits owned by, say, Russian residents in Switzerland, or by 
Germans in Jersey. We use these data to make two contributions.

First, we construct estimates of the amount of wealth held by each country in all the world's offshore tax havens. More precisely, we use the newly disclosed BIS bilateral banking statistics to allocate the global amount of offshore wealth estimated by Zucman (2013) to each of the world's country. To our knowledge, it is the first time that such country-by-country estimates of offshore wealth are computed.

The analysis of this new dataset reveals a number of striking results. We find that while about $10 \%$ of world GDP is held in tax havens globally, this average masks a great deal of heterogeneity. Scandinavian countries own the equivalent of only a few percent of GDP in offshore wealth, but this figure rises to about $15 \%$ in Continental Europe, and to as much as $60 \%$ in Russia, Gulf countries, and a number of Latin American countries. The size of offshore wealth is not easily explained by tax or institutional factors. Among countries with a large stock of offshore assets, one finds autocracies (Saudi Arabia, Russia), countries with a recent history of autocratic rule (Argentina, Greece), alongside old democracies (United Kingdom, France). Among those with the lowest stock of offshore assets, one finds relatively low-tax countries (Korea, Japan) alongside the world's highest tax countries (Denmark, Norway). Instead, geography and specific national trajectories seem to matter a great deal. Proximity to Switzerland-the first country that developed a cross-border wealth management industry, in the $1920 \mathrm{~s}$ - is associated with higher offshore wealth, as is the presence of natural resources, and political and economic instability post-World War II.

Our second contribution is to investigate the implication of offshore wealth for the levels and trends in wealth concentration. In recent years, following the pioneering work of Kuznets (1953) and Atkinson and Harrison (1978), a number of studies have used tax data to construct top income and wealth shares for many countries (see Roine and Waldenström, 2015, for a survey). A key concern raised by the use of tax returns to measure inequality, and indeed one of the main reasons why tax data have for a long time been viewed with skepticism, is tax avoidance and evasion. Tax records only provide information about income (and wealth, when a wealth tax exists) reported to the tax authority, not true economic income and wealth. Due to tax progressivity, the rich have particularly strong incentives to understate their resources. We construct revised top wealth shares factoring in offshore assets for ten countries where wealth distributions have recently been estimated-Denmark, Finland, France, the Netherlands, Norway, Russia, Spain, Sweden, the United Kingdom, and the United States.

Because offshore wealth is very concentrated at the top, accounting for it increases the top 
0.01\% wealth share substantially, even in countries - such as Norway or Denmark - that do not use tax havens extensively. Offshore wealth has a larger effect on inequality in the U.K., Spain, and France, where, by our estimates, 30\%-40\% of all the wealth of the $0.01 \%$ richest households is held abroad. It has dramatic implications in Russia, where the majority of wealth at the top is held outside of the country. In the United States, offshore wealth also increases inequality, but the effect is more muted than in Europe, because U.S. top wealth shares are already very high even disregarding tax havens. In all cases, taking offshore wealth into account increases the rise in inequality seen in tax data markedly. This result highlights the importance of looking beyond tax data to study wealth accumulation among the very rich in a globalized world.

Our paper is part of a broader project, initiated in Alstadsæter, Johannesen, and Zucman (2017), aimed at studying the size and distribution of tax evasion and its implication for inequality. In Alstadsæter, Johannesen, and Zucman (2017), we use a variety of micro-data-random audits, leaks from offshore financial financial institutions (HSBC Switzerland, Mossack Fonseca), and tax amnesties - to study how tax evasion varies with wealth. In all the micro-data we have access to, offshore wealth turns out to be extremely concentrated: the top $0.1 \%$ richest households own about $80 \%$ of it, and the top $0.01 \%$ about $50 \%$. This finding leads us to revise upward the top Scandinavian wealth shares. Here we draw on macro data to generalize the computations made in Alstadsæter, Johannesen, and Zucman (2017) to more countries. We take the distribution of hidden wealth observed in leaks and amnesties and apply this distribution to our newly constructed country-by-country estimates of offshore wealth.

At the outset, it is worth stressing that measuring offshore wealth involves a margin of error. First, the BIS statistics that we rely on only cover bank deposits, not the portfolios of equities, bonds, and mutual fund shares that households entrust to offshore banks. The distribution of offshore bank deposits across countries, however, is likely to be strongly correlated with that of total offshore wealth, so that the orders of magnitude we obtain are likely to be robust. Second, the use of anonymous shell corporations makes it increasingly hard to identify the beneficial owners of the wealth held offshore. In the macroeconomic data we use, a growing amount of wealth is assigned to the British Virgin Islands, Panama, and similar tax havens where most of the world's shell corporations are domiciled. The use of shell companies has increased particularly fast since the mid-2000s (for reasons discussed in Section 4 below). We therefore choose to express our estimates for the mid-2000s (more precisely for 2006-2007), when the available statistics are less contaminated by shell companies than today. Our results provide a snapshot of offshore wealth on the eve of the global financial crisis. In Section 3, we 
discuss a number changes that have happened since the Great Recession and how they have affected the dynamic of offshore wealth, but we leave to future research the task of establishing country-by-country time series of offshore wealth. Third, for the purpose of investigating the implications of offshore wealth for inequality, we assume that the distribution of hidden assets seen in recent leaks and tax amnesties (as analyzed in Alstadsæter, Johannesen, and Zucman, 2017) applies to all countries. This is a reasonable starting point, because the distribution of hidden assets by wealth group is remarkably similar in all the available sources. But one cannot exclude that offshore wealth is more or less concentrated in certain countries. Looking forward, we plan to expand and refine our approach as new sources of information emerge about the size and distribution of offshore assets (maybe from new leaks, or thanks to improvements in financial transparency) and wealth inequality statistics become available for more countries.

The rest of the paper proceeds as follows. Section 2 relates our work to the existing literature. In Section 3, we present our estimates of the amount of wealth held in tax havens globally, updating the analysis of Zucman (2013). In Section 4, we use bilateral banking statistics to construct new country-by-country estimates of the world's offshore wealth. We discuss the implications of our results for wealth inequality in Section 5 and conclude in Section 6. This paper is supplemented by a Data Appendix available online at http://gabriel-zucman.eu/ offshore.

\section{$2 \quad$ Related Literature}

\subsection{Offshore Wealth and Capital Flight}

Our paper first contributes to the literature on offshore wealth and capital flight. A large number of studies attempt to estimate the flows of money, licit or illicit, that leave developing countries. Johannesen and Pirtillä (2016) provide a recent survey of the data, methods, and results. One prominent strand of the literature relies on accounting identities in the balance of payments, in particular discrepancies between a country's current account surplus and the flow of net new foreign investments - what is known as net errors and omissions. This method has been used by international organizations like the World Bank and the United Nations (e.g., Claessens and Naudé, 1993; UNDP, 2011), non-governmental organizations such as the Tax Justice Network (e.g., Henry 2012), and academics (e.g., Pastor,1990; Boyce, 1992; Lensink et al., 2000).

Our approach differs from most of these studies in a number of dimensions. First, we attempt to estimate stocks of wealth rather than flows. Second, we try to base our estimates as much as 
possible on direct, official statistics on the stock of offshore assets. Most importantly, the Swiss central bank publishes detailed statistics on the amount of offshore wealth managed by Swiss banks. Due to the outsized role played by Switzerland in cross-border wealth management, this data source alone (first analyzed in Zucman, 2013) plays a key role in our estimates, as described in Sections 3 and 4 below. ${ }^{1}$ Third, to our knowledge we are the first to use the bilateral bank deposit data of the Bank for International Settlements to estimate the stock of offshore wealth owned by each country in the tax havens other than Switzerland. ${ }^{2}$

In our view, both the net-errors-and-omissions approach and the one we apply in this paper have merits; we view them as complementary. Our approach is likely to deliver conservative results, because it only captures financial wealth, disregarding valuables, works of art, real estate, and other non-financial assets. The net-errors-and-omissions approach is broader in scope, at is captures not only financial assets held offshore, but also real assets, the wealth of households who change residency, and - in some variants - some foreign assets managed by domestic financial institutions. This approach is valuable, and indeed we also rely on net errors and omissions to provide an estimate of Russia's offshore wealth, which we contrast to the estimate we obtain from observable BIS bank deposits (see Section 4 below).

\subsection{Top Income and Wealth Shares}

We also contribute to the literature on inequality. Over the last fifteen years, there has been renewed interest for the long-run evolution of the distribution of income and wealth. Following the pioneering work of Kuznets (1953) and Atkinson and Harrison (1978), a number of studies have used tax data to construct top income and wealth shares for many countries. ${ }^{3}$ Two central findings have so far emerged from this research: inequality declined sharply in the Western world during the first half of the twentieth century, and it has increased since the 1980s, albeit much more in the United States than in Europe. A key driver of these evolutions has been long-run changes in the level and concentration of wealth. The main reason why inequality fell

\footnotetext{
${ }^{1}$ However, no country other than Switzerland publishes data as detailed as those of the Swiss central bank; as a result, our estimate of the world's offshore wealth also relies on indirect method to capture the wealth managed outside of Switzerland; see Section 3 below.

${ }^{2}$ Estimates of offshore wealth for the main continents (Europe, Africa, Asia, etc.) and a few countries (United States, Russia, Canada, France) were produced by Zucman $(2014,2015)$, but based on much less data, as the BIS bilateral banking statistics had not yet become available.

${ }^{3}$ See, e.g., Piketty and Saez (2003) for U.S. top income shares, Saez and Zucman (2016) for U.S. top wealth shares, Atkinson et al. (2011) for a survey, and Piketty (2014) for a broad interpretative synthesis. Top income and wealth share series are collected in the World Wealth and Income Database, http://wid.world (Alvaredo et al., 2017). See also Lampman (1962) for an early attempt to estimate wealth distribution from estate tax data.
} 
during the first half of the twentieth century is a series of large shocks to capital - the World Wars, the Great Depression, anti-capital policies such as steeply progressive capital taxation, nationalizations, and rent controls - which reduced the importance of wealth relative to income and the concentration of capital (Piketty and Zucman, 2014; Piketty, 2014). More recently, labor income inequality has stabilized in the United States since the beginning of the twenty first century; top income shares have mostly risen because of rapid wealth accumulation at the top (Saez and Zucman, 2016; Piketty, Saez and Zucman, 2017). In both cases, changes in wealth concentration among the rich play a key role for the dynamic of overall inequality.

The rise of tax havens raises a serious issue for this literature. Tax havens barely existed before World War I, when the direct taxation of income and wealth was in its infancy and top marginal tax rates did not exceed a few percents. Cross-border wealth management first developed in Switzerland in the 1920s, but until the 1980s there was no other country where one could easily hide assets. Since the 1980s, tax havens have flourished. This could bias time-series and cross-country and comparisons of top income and wealth shares in multiple directions. Tax records, for instance, may exaggerate the secular decline in wealth concentration from its high pre-World War I level seen in most developed countries, or they could over-state the gap between the United States and Europe today.

The literature on inequality has discussed the potential problems raised by top-end tax avoidance and evasion (e.g., Atkinson, Piketty, Saez, 2011, pp. 36-40), but until recently there was little data that would allow to systematically quantify it. Larudee (2016) investigates the extent to which capital flight to Switzerland can explain the decline in the French top 1\% income share between the two world wars. Roine and Waldenström (2008) and Martínez-Toledano (2017) are the only papers that focus on the distributional implications of offshore wealth for the recent period. Roine and Waldenström (2008) use the net-errors-and-omissions approach described above (and similar residuals in the financial accounts) to estimate the amount of wealth hidden by Swedish residents, and assume that this wealth primarily belongs to the top, while Martinez-Toledano (2017) uses amnesty data in Spain. One of our contributions in this paper is that we are able to analyze the implications of offshore wealth for a larger sample of countries. 


\section{The Global Amount of Wealth in Tax Havens}

\subsection{Data and Methodology}

We are interested in quantifying the wealth that households own outside of their country of residence, and is therefore hard to observe and tax by domestic authorities: offshore bank deposits; portfolios of bonds, equities, mutual fund shares, and derivatives managed by foreign financial institutions; gold, diamonds and works of art stashed in vaults and "freeports" abroad, and foreign real estate. Because no systematic information exists on offshore real estate and other non-financial assets, we restrict our attention to offshore financial wealth, which is the most important form of wealth at the top. While quantifying offshore financial wealth involves a margin of error, this exercise can be conducted fairly rigorously and precisely, because there exists several official, direct, and publicly available statistics on the wealth held in tax havens. Some of these data raise difficulties, as we discuss below, but taken together they paint a consistent picture.

There are three main data sources to measure offshore financial wealth. First, and most importantly, the central bank of Switzerland publishes detailed statistics on the bank deposits, portfolios of equities, bonds, and mutual fund shares managed by Swiss banks on behalf of foreigners. ${ }^{4}$ Thus, we know that foreigners owned $\$ 2.3$ trillion in Swiss banks in April 2017. Because Switzerland has historically played an outsized role in cross-border wealth management, this data source alone captures a large fraction of the world's total offshore wealth $(30 \%-50 \%$ in recent years). Second, all significant offshore financial centers-including Hong Kong, Singapore, the Cayman Islands, and the Bahamas - disclose statistics on the amount of deposits owned by foreigners in their banks. The main limitation of these data, which are disseminated by the Bank for International Settlements, is that they miss the largest form of offshore wealth, namely portfolio securities. Third, we can have a sense of the global amount of offshore portfolio securities by looking at specific anomalies in global investment statistics. The equities, bonds, and mutual fund shares owned by households on foreign accounts are duly recorded on the liability side of the international investment positions of countries (the stock equivalent of the balance of payments), but not on their assets side. This causes a discrepancy between global portfolio liabilities and assets. ${ }^{5}$ Using these anomalies, Zucman (2013) estimates that

\footnotetext{
${ }^{4}$ See Zucman (2013, Section III; and 2015, chapter 1) for a detailed presentation of this unique, high-quality dataset.

${ }^{5}$ Similar anomalies are observable at the flow level. In the world's balance of payments published by the International Monetary Fund, more income is systematically paid than received. In 2015, the gap reached $\$ 255$ billion. This gap can be decomposed into a primary income discrepancy of $\$ 78$ billion, and a secondary
} 
the equivalent of $10 \%$ of the world's GDP is held offshore. A similar estimate is obtained by Pellegrini, Sanelli, and Tosti (2016).

\subsection{Global Offshore Wealth and Its Evolution Since 2001}

Figure 1 shows the evolution of global offshore wealth since 2001, estimated using the same methods and data sources as in Zucman (2013) but drawing on the latest available international investment positions of countries. We find that the stock of offshore wealth has remained equal to about $10 \%$ of world GDP, with no particular trend. ${ }^{6}$ Based on interviews with wealth managers, the Boston Consulting Group also estimates global offshore financial wealth. As shown in Figure 1, BCG's estimate is larger than ours, typically by 2 to 3 points of world GDP, but it displays the same time trend. The similarity of the estimates which are based on different methods (macroeconomic statistics on the one hand; interviews with a panel of bankers in tax havens on the other) lends support to the view that $10 \%$ of world GDP is the correct order of magnitude for the amount of financial wealth held in tax havens.

If anything, this order of magnitude - which corresponds to $\$ 5.6$ trillion in 2007 , our benchmark year in this paper - is likely to be conservative. The OECD calculates that households owned a total of $\$ 5$ to $\$ 7$ trillion offshore in 2007 (Owens, 2007); Cap Gemini and Merrill Lynch (2002) have a \$8.5 trillion figure for 2002; Palan, Murphy, and Chavagneux (2010) write that "the global rich held in 2007 approximately $\$ 12$ trillion of their wealth in tax havens;" and Henry (2012) finds $\$ 21$ to $\$ 32$ trillion as of 2010. One limitation of Zucman's (2013) methodology is that it only captures financial wealth, disregarding valuables, works of art, real estate, and other non-financial assets.

Switzerland alone - where offshore wealth is directly observable in official statistics - hosts a large fraction of our estimated global amount of offshore wealth: 40\% of the total in 2001, peaking at $45 \%-50 \%$ in 2006-2007, and declining to $30 \%$ in recent years. The rest is held in the other cross-border wealth management centers. Figure 2 shows where the world's offshore wealth is located, based on the amount of cross-border bank deposits managed in each offshore

income discrepancy of $\$ 177$ billion. In practice, it is difficult to separate cross-border primary income (which in principle should include cross-border dividends and interest) from cross-border secondary income (which in principle should mostly include remittances).

${ }^{6}$ Because of valuation effects on the equities held offshore, the ratio of offshore wealth to world GDP rises during stock market booms and falls during busts. Another way to quantify the importance of offshore wealth that neutralizes valuations effects involves dividing it by the world's household financial wealth. Offshore wealth appears to be stable at about $8 \%$ of global household financial wealth over the 2001-2015 period. Not all countries publish financial accounts, however, so there is a bit more uncertainty on the value of global household financial wealth than world GDP. 
center. $^{7}$ While Switzerland has been declining since the financial crisis of 2008-2009, Asian offshore centers have been on the rise. The increase in offshore wealth has been particularly strong in Hong Kong. In 2007, Hong Kong managed less offshore wealth than Jersey, the Bahamas or the Cayman Islands. From 2007 to 2015, its assets under management have been multiplied by a factor of 6 , and Hong Kong now ranks second behind Switzerland. ${ }^{8}$

\section{Country-by-Country Estimates of Offshore Wealth}

In order to estimate how much each country owns in tax havens, we start with the global amount of offshore wealth and allocate this total to each of the world's country. We do this allocation for the middle of 2007, when, by our estimate, a total of $\$ 5.6$ trillion was held in tax havens globally. Since close to half of the world's offshore wealth was held in Switzerland in 2007, and the Swiss data are of particularly high quality, we conduct our allocation in three steps. We first estimate how much each country owns in Switzerland, then estimate how much each country owns in the tax havens other than Switzerland, and last combine the two distributions. We discuss each step in turn.

\subsection{Who Owns the Wealth in Switzerland?}

The Swiss central bank has been publishing a country-by-country breakdown of the wealth owned by foreigners in Swiss banks annually since the 1970s. These data cover all the banks located in Switzerland, including the subsidiaries of foreign banks and excluding the subsidiaries of Swiss banks abroad. They provide information on a specific type of wealth, known as fiduciary deposits, which is large and likely to be representative of all the offshore wealth managed by Swiss banks. Fiduciary deposits are akin to money market funds: Swiss banks invest the money put in fiduciary deposits in foreign money markets on behalf of their clients. Legally speaking, all interest is considered to be paid by foreigners to the depositors, with the Swiss banks acting

\footnotetext{
${ }^{7}$ In order to compute the amount of offshore wealth in each offshore center, we assume that the ratio of deposits to portfolio securities is the same everywhere. In addition, we use statistics published by domestic central banks to estimate what fraction of cross-border bank deposits belong to households vs. corporations (see Johannesen and Zucman, 2014, for a discussion of these data) and we exclude all the wealth that belongs to corporations. For instance, the available evidence suggests that about $90 \%$ of the cross-border bank deposits in the United Kingdom belong to corporations, so we only include $10 \%$ of the UK's bank deposits under the line "offshore wealth in the other European tax havens" in Figure 2. Generally speaking, most deposits tend to belong to households in offshore centers specialized in private wealth management (such as Switzerland, the Channel Islands, Luxembourg, or Singapore) while most belong to corporations in big financial centers that provide a wide array of international financial services (such as the United Kingdom and the United States). Our series therefore put a much higher weight on Switzerland or Luxembourg than on the U.K. or the U.S. See Appendix Table A.2 for detailed computations.

${ }^{8}$ See Appendix Figure 2a, 2b, and 2c; and Appendix Tables 2a, 2b, and 2c.
} 
merely as "fiduciaries". For that reason, interest earned on fiduciary deposits is not taxed in Switzerland, contrary to interest earned on regular bank deposits, which is subject to a $35 \%$ withholding tax. In 2007, fiduciary deposits accounted for about $25 \%$ of all the offshore wealth managed by Swiss banks. ${ }^{9}$

The main difficulty raised by the Swiss data is that a large fraction of the wealth held in Switzerland - as in most other offshore centers-belongs on paper to shell companies, trusts, foundations, and personal holding companies incorporated in other tax havens. As a result, a significant fraction of the offshore wealth managed by Swiss banks is assigned to the British Virgin Islands, Panama, or Jersey in the statistics. The use of shell companies increased after 2005, when in the context of a law known as the Saving Tax Directive, the European Union introduced a tax on interest income earned by E.U. residents in Switzerland and other tax havens. Because the tax did not apply to accounts nominally owned by shell companies, European depositors massively shifted their assets to shell companies (see Zucman 2013; Johannesen 2014; Johannesen and Zucman 2014; Roussille 2015).

To address this issue, we estimate the country distribution of the offshore wealth managed by Swiss banks by using the data for 2003-2004, just before the EU Saving Tax Directive enters into force. Before the Directive, there is no particular evidence that residents of some countries used shell corporations more than others (while after 2005, Europeans are more likely to do so). We assume that if a country owns $10 \%$ of the wealth not owned via shell companies in 2003-2004, it also owns 10\% of the wealth owned via such shells. Figure 3 shows the resulting distribution of the offshore wealth held in Switzerland. Countries above the 45-degree line own a greater share of Swiss wealth than their share of world GDP would imply. This group is heterogeneous: it includes Middle-Eastern oil exporters (Saudi Arabia, United Arab Emirates), a number of Continental European and Latin American countries (Spain, France, Belgium, Argentina, Venezuela), and various autocracies (Egypt, Jordan). The group of countries that do not own much wealth in Switzerland relative to the size of their economy is diverse too, encompassing high-tax Scandinavian countries (Denmark, Norway, Sweden), low-tax OECD countries (Japan and South Korea), democracies (India), alongside autocracies (China).

To assess the robustness of the distribution shown in Figure 3, we use data leaked from HSBC Switzerland, the Swiss subsidiary of the banking giant HSBC, analyzed in Alstadsæter, Johannesen, and Zucman (2017). In 2007 a systems engineer, Hervé Falciani, extracted the complete list of HSBC Switzerland's 30,412 clients and of their holdings, which totaled $\$ 118.4$

\footnotetext{
${ }^{9}$ Since 2008 , the share of fiduciary deposits has declined to less than $10 \%$, because short-term interest rates have fallen to zero or close to zero.
} 
billion. A country-by-country breakdown of the wealth held at HSBC Switzerland is published by the International Consortium of Investigate Journalists. ${ }^{10}$ These statistics only cover one (important) bank, but they have a key advantage: in most cases, the files leaked by Falciani allow to link the accounts owned by shell companies to their actual owner. As shown in Alstadsæter, Johannesen, and Zucman (2017, Figure 2), the country distribution of the wealth managed by HSBC Switzerland turns outs to be remarkably similar to the distribution we estimate for the entire Swiss banking industry.

\subsection{Offshore Wealth in the Tax Havens Other than Switzerland}

Most tax havens other than Switzerland also compile statistics on who owns wealth in their banks. Until recently they did not publish them, but this changed in 2016 when many offshore centers authorized the Bank for International Settlements to disseminate bilateral banking statistics (e.g., the amount of deposits owned by Indian residents in Hong Kong). Importantly, these series are retrospective, and go back in most cases to the early 2000s, or even earlier. As of August 2017, Guernsey, Hong Kong, the Isle of Man, Jersey, Luxembourg, Macao, and Switzerland reported bilateral current and historical banking statistics through the BIS. A number of offshore centers still did not, most notably the Bahamas, Singapore, and the Cayman Islands. The deposits owned in these centers, however, can be estimated as a residual.

The BIS bilateral banking statistics are generally of high quality. All banks above a modest size threshold (typically about 10 million dollars in assets) have to report. The data have been collected for a long time - sometimes as far back as the 1970s - and reporting practices have improved over time. This paper is not the first to use these data for research purposes (see, e.g., Johannesen and Zucman, 2014); a number of prior studies obtained access to them when they were available to some institutions (e.g., central banks) with strict confidentiality agreements. However these agreements typically prohibited publication of statistics at the bilateral level, so the data could not be used to construct estimates of offshore wealth. The main limitation of the BIS data is that bank deposits only account for a fraction of total offshore wealth, so we need to make assumptions. We assume that if Indians own 10\% of the bank deposits in Hong Kong, then they also own $10 \%$ of the offshore wealth held there-i.e., that the distribution of deposits is the same as that of offshore wealth. In practice, the correlation between the two distributions is likely to be high but imperfect. For instance, U.S. corporations may own the bulk of the bank deposits in the Cayman Islands, while U.S. households might own a smaller

\footnotetext{
${ }^{10}$ http://projects.icij.org/swiss-leaks/.
} 
fraction of the total offshore wealth in the Caymans. With the data at our disposal, we cannot quantify the size of the potential bias. Its impact on our country-by-country offshore wealth estimates is likely to be limited, however, because in 2007 close to half of all offshore wealth was held in Switzerland, where the data allow us to tease out corporations from households.

Figure 4 contrasts the distribution of the wealth held in Switzerland and in the other offshore centers. Countries below the 45-degree line tend to favor Switzerland, while countries above it tend to favor the other private wealth management centers-among which the largest in 2007 were Singapore, Luxembourg, Jersey, and the Cayman Islands. We find that Asian economies typically have a small fraction of the wealth in Switzerland, but a higher fraction of that managed elsewhere (due in particular to Singapore, which caters largely to Asian investors). Russia has both a lot of wealth in Switzerland and in the other tax havens (mostly Cyprus). A number of European countries, such as France, Belgium, Portugal, are close to the 45-degree line, as they own a large fraction of the wealth managed in Luxembourg and Jersey. Middle-Eastern countries overwhelmingly favor Switzerland, probably in part for historical reasons, since Switzerland was the only banking center with a developed wealth management industry at the time of the oil boom of the 1970s. By contrast, the United States - not displayed on the graph due to its outlier status - owns a much greater share of the assets held outside of Switzerland (33\%) than in Switzerland (3\%). It owns the bulk of the wealth in the Cayman Islands. ${ }^{11}$

\subsection{Country-by-Country Estimates of Offshore Wealth}

We obtain country-by-country estimates of offshore wealth by adding up the wealth held in Switzerland and in the other tax havens. The results are reported in Figure 5, where we show the ratio of offshore wealth to GDP for all countries with more than $\$ 200$ billion in GDP in $2007 .^{12}$ For Russia, we report two estimates: one following the same methodology as for all other countries, and another one obtained by cumulating net errors and omissions following the methodology described in Novokmet, Piketty, and Zucman (2017). This alternative estimate is broader in scope, at it includes real assets owned offshore (instead of financial assets only), and the wealth of non-residents (which is large in the Russian context) on top of offshore assets belonging to residents only.

We find that while about $10 \%$ of world GDP is held in tax havens globally, this fraction varies a lot across countries. As shown by Figure 5, Scandinavian countries own the equivalent of only a

\footnotetext{
${ }^{11}$ See Appendix Table A.3.

${ }^{12}$ Results for all countries are presented in Appendix Table A.3. See also Appendix Figure A.4 (for African countries), A.5 (for Asian countries), A.6 (for European countries), and A.7 (for Latin America).
} 
few percent of GDP in offshore wealth, but this figure rises to about 15\% in Continental Europe, and to as much as $60 \%$ in Russia, Gulf countries, and a number of Latin American countries. The size of offshore wealth is not easily explained by tax, financial or institutional factors. Among countries with a large stock of offshore assets, one finds autocracies (Saudi Arabia), countries with a recent history of autocratic rule (Argentina, Greece), alongside old democracies (United Kingdom, France). One also finds countries with a highly developed domestic financial industry (Belgium, Germany) alongside countries with poorly developed financial institutions (Venezuela) as measured by Čihák et al. (2012). Among countries with the lowest stock of offshore assets, one finds low-tax economies (Korea) alongside the world's highest tax countries (Denmark, Norway). Instead, geography and specific national trajectories seem to matter a great deal. Proximity to Switzerland-the first country that developed a cross-border wealth management industry, in the 1920s - is associated with higher offshore wealth, as is the presence of natural resources, and political and economic instability post-World War II. These patterns are consistent with the analysis of Andersen et al. (2016), who find that flows to tax havens vary systematically with windfall gains in the oil industry and political shocks, such as elections and coups.

A case in point is the contrast between Russia (where private and offshore wealth boomed in the 2000s as oil and gas prices rose) and China. According to our estimates, the offshore wealth of China amounts to only $2.3 \%$ of its GDP, 20 times less than in Russia-when using net error and omissions to estimate Russia's offshore wealth - or 6 times less when relying on the BIS data. However, one should keep in mind that these estimates are for 2007, at a time when Hong Kong still played a minor role in cross-border wealth management. Because of the boom in the Hong Kong private banking industry, it is likely that China's offshore wealth has increased since 2007. Estimating the offshore wealth of China in recent years raises complicated issues, however, due to the changing integration of Macao and Hong Kong with mainland China, and the rise of shell companies. We leave this task to future research.

As with any attempt to measure the unrecorded economy, our country-by-country estimates of offshore wealth involve a margin of error. However, we believe that they are globally reliable, for one simple reason: by construction our country figures sum up to the world's offshore wealth, which itself is by design fully consistent with the international investment positions of countries, central bank data, and official statistics published by tax havens - and is at the low-end of the scale of available estimates (Figure 1). Our figures can all be reproduced step-by-step using publicly available statistics; we therefore see them as a useful starting point. To assess their 
reliability, we conduct the following robustness checks: we compare our estimates of offshore wealth to data that have become available in 2016 in the context of the Panama Papers.

\subsection{Robustness Test: Comparison with the Panama Papers}

In the Spring of 2016, the International Consortium of Investigative Journalists published the names and addresses of the owners of all the shell companies created by the Panamanian firm Mossack-Fonseca. This leak, known as the Panama Papers, provides information on shell corporations that were created over two decades. At the time of the leak, Mossack-Fonseca was a major provider of offshore financial service; the available evidence suggests it was one of the world's five largest purveyor of shell companies. It is therefore informative to analyze who the owners of the shell corporations created by this firm are.

Figure 6 depicts the number of unique owners of shell companies created by Mossack-Fonseca in each of the world's country (normalized by 2007 GDP). The sample includes all the owners of shell companies that were created by Mossack-Fonseca before 2006 and were still active in 2007. For instance, there are 2,071 unique Russian owners of such shells. ${ }^{13}$ There are strong similarities between the amount of offshore wealth we estimate and the use of tax havens as revealed by the Panama Papers. Among the countries that created a lot of shell companies (relative to the size of their economy), one finds Jordan, Russia, Taiwan, the U.A.E., Venezuela, Zimbabwe, Kenya - which all have high offshore wealth to GDP ratios. The main exception is China, who is over-represented in the Mossack-Fonseca data. One interpretation is that Chinese residents do not use shell companies to conceal wealth in foreign banks, but to circumvent a number of regulations that restrict cross-border investments in and out of China. Another possible interpretation is that we under-estimate the amount of Chinese offshore wealth - maybe precisely because an abnormally high fraction of it is held through shell companies. ${ }^{14}$

Restricting the analysis to high-tax OECD countries, Figure 7 shows that there is a strong correlation between how much each country owns in wealth offshore, and the number of owners

\footnotetext{
${ }^{13}$ See Appendix Table A.4. Our results are consistent with the findings of Omartian (2017), who uses the Panama Papers to study the impact of information exchange agreements on the creation of shell companies.

${ }^{14}$ In addition to China, a number of low-tax countries - in particular in Eastern Europe (Estonia, Latvia, Moldova, etc.) - appear to own a lot of shell companies and yet according to our estimates don't own much offshore wealth. The most likely explanation is that the owner of a shell company can be another shell company, typically incorporated in a low-tax country; hence the addresses of registered owners in the Panama Papers leak do not always reflect the country of residence of the ultimate owners. To deal with this issue, in Figure 6 we exclude owners who own more than 10 different shell companies and owners with addresses in tax havens, both of which are likely to be nominees (such as other shell companies) instead of actual persons. But countries like Estonia, Latvia, and Moldova are not classified as tax havens in standard lists, and it is likely that most of the shells assigned to Estonian or Latvian owners actually belong to persons domiciled in other countries.
} 
of Mossack-Fonseca shell companies. Greece, by our estimate, owns 40\% of its GDP in offshore wealth, and it turns out it also features prominently in the Panama Papers. At the other end of the spectrum, Scandinavian countries have low stock of offshore wealth and few owners of Mossack-Fonseca shell companies. Overall, these findings corroborate the view that our countryby-country estimates of offshore wealth are likely to be reliable. Looking forward, new leaks or improvements in financial transparency might enable us to improve our estimates.

\section{Implications for Top Wealth Shares}

In this Section, we investigate the implications of offshore wealth for the measurement of wealth inequality. Over the last few years, a number of studies have estimated top wealth shares using tax data. As a result, we now have access to wealth distribution estimates that are reasonably comparable for ten countries, which together accounted for close to half of world GDP (using market exchange rates) in the 2000s: Denmark, Finland, France, the Netherlands, Norway, Russia, Spain, Sweden, the United Kingdom, and the United States. We investigate how taking offshore wealth into account modifies wealth inequality in these ten countries, focusing on the 2000s. ${ }^{15}$

\subsection{Methodology to Correct Top Wealth Shares}

To correct top wealth shares, we start from our estimate of the stock of offshore wealth owned by each country. From there we need two ingredients: what fraction of the wealth held offshore is visible in the data used to estimate wealth concentration (typically, tax records), and how offshore assets are distributed across wealth groups. We discuss these two ingredients in turn.

First, there is a great deal of evidence that the vast majority of offshore wealth was not reported on tax returns in the 2000s. Two U.S. Senate $(2008,2014)$ reports found that $90 \%$ of the wealth held by U.S. citizens at UBS and Credit Suisse was undeclared in 2008; Johannesen and Zucman (2014) and Roussille (2015) find that $90 \%$ of the wealth held by Europeans in Switzerland was undeclared; $90 \%-95 \%$ of the wealth owned by Danish and Norwegian households at HSBC Swtizerland was not declared either (Alstadsæter, Johannesen, and Zucman, 2017). Even when no illegal tax evasion is involved, offshore wealth is typically structured in a way that it does not generate taxable income nor reportable assets. This is done by combining trusts, foundations, and holding companies, so as to disconnect assets from their beneficial own-

\footnotetext{
${ }^{15}$ For two countries, Finland and Netherlands, no estimates of the top $0.01 \%$ wealth share are available, so when investigating the impact of offshore wealth on the top $0.01 \%$, our sample is restricted to eight countries.
} 
ers (Harrington, 2016). These arrangements can be legal or illegal, but typically imply that tax authorities will not observe much offshore wealth or investment income earned offshore, except in exceptional circumstances (e.g., a taxable and properly declared inter-generational transfer of assets). In this paper, we do not take a stance on what fraction of offshore assets illegally evade taxes, but we assume that offshore wealth was not visible to tax authorities in the 2000s. Since our estimates of offshore wealth are conservative, we do not believe our overall methodology overstates the importance of offshore assets for the measurement of inequality.

Second, we distribute the macro stock of offshore wealth across wealth groups based on how offshore assets are distributed in the micro-data studied by Alstadsæter, Johannesen, and Zucman (2017), namely the HSBC leak (discussed in Section 4 above) and large samples of Scandinavian taxpayers who voluntarily disclosed previously hidden assets in the context of tax amnesties. Offshore wealth is similarly distributed in both data sources, and extremely concentrated: about $80 \%$ of it belongs to the top $0.1 \%$ richest households, and about $50 \%$ to the top $0.01 \%$. There is no evidence that HSBC Switzerland catered to ultra-wealthy individuals only, nor that only the very rich use tax amnesties (in fact, the available evidence suggests that self-selection into amnesties is slightly negatively correlated with wealth; see Alstadsæter, Johannesen, and Zucman, 2017, Section 3). We therefore view these distributions as a reasonable starting point. Of course, it is unlikely that offshore wealth is distributed in exactly the same way in all the world's countries; but it is also highly unlikely that a large fraction of it belongs to households in the bottom $99 \%$ of the wealth distribution. Offshore private banks typically require customers to have a minimum amount of financial assets to invest (e.g., \$1 million, or $\$ 10$ million - levels of financial wealth above which one is typically in the top $1 \%$ or top $0.1 \%$, respectively). In the Online Appendix Tables A.9, A.10, and A.11, we consider how different distributions affect our results; for all plausible distributions, the impact on our findings is second-order.

\subsection{How Offshore Wealth Affects Top Wealth Share}

Figure 9 shows the top $0.01 \%$ wealth share in our sample of countries, including vs. excluding offshore wealth. We find that accounting for offshore assets increases the top $0.01 \%$ wealth share substantially, even in countries - such as Scandinavian economies - that do not use tax havens extensively. The magnitude of the effect, however, varies a lot across countries. In Scandinavia, the top $0.01 \%$ wealth share rises from about $4 \%$ to about $5 \%$. Offshore wealth has a larger effect on inequality in the U.K., Spain, and France, where, by our estimates, 30\%-40\% of all the 
wealth of the $0.01 \%$ richest households is held abroad. While France appears more equal than Scandinavia when disregarding offshore assets, it becomes more unequal when factoring it. The United Kingdom - which, according to Alvaredo, Atkinson and Morelli (2017), is more equal than Scandinavia and France-becomes comparable to these economies. Offshore wealth has dramatic implications in Russia, where the vast majority of wealth at the top is held outside of the country. In the United States, offshore wealth also increases inequality, but the effect is more muted than in Europe, because U.S. top wealth shares are already very high even disregarding tax havens. ${ }^{16}$ We obtain similar qualitative results for the top $0.1 \%$ wealth share (see Appendix Figure A.11).

Taking offshore wealth into account also increases the rise in inequality seen in tax data markedly. In Figure 9, we correct the top $0.01 \%$ wealth share of France and the United Kingdom as far back as 1950. To do so, we assume that prior to the 2000s, the stock of offshore assets owned by these two countries followed the same evolution as the overall amount of offshore wealth managed by Swiss banks (and that hidden wealth was as concentrated in the past as today). Although a sizable margin of error is involved here, the broad patterns are likely to be robust: all the available evidence suggests that although the wealth held by Europeans in Switzerland was already far from insignificant in the post-World War II decades, it is in the 1980s and 1990s that it grew the most. ${ }^{17}$ Accordingly to our estimates, once offshore wealth is factored in, the top $0.01 \%$ wealth share is now significantly higher in France today than it was in the early 1950s - contrary to what the raw estimates of Garbinti, Goupille and Piketty (2017) suggest. This result highlights the importance of looking beyond tax data to study wealth accumulation among the very rich in a globalized world. ${ }^{18}$ The effect of offshore wealth on the dynamic of wealth concentration is less marked in the United Kingdom, because wealth inequality was much higher in the U.K. in the 1950s than in France (with a top 0.01\% wealth share more than twice higher: $10 \%$ vs. $4 \%$ ).

\footnotetext{
16 Because most income at the top of the distribution (close to $100 \%$ for the top $0.01 \%$ and upper groups) derives from wealth, our results imply that the very top income shares are also similarly under-estimated, by a similar proportional factor.

${ }^{17}$ In the 1990s, two international commissions got access to the archives of Swiss banks. Drawing on the work of these commissions, Zucman (2015, chapter 1) constructs historical series for the amount of foreign wealth managed by Swiss banks back to the early twentieth century. We refer to Zucman (2015) for a detailed description of these series.

${ }^{18}$ One caveat, however, is that the fraction of offshore wealth duly declared to tax authorities (hence potentially observable in tax data) may have increased since 2013, when many tax havens promised to exchange bank information automatically with foreign tax authorities (in most cases starting in 2017-2018). Because they cannot easily be audited by foreign governments, and because some of them might still find it profitable to sell tax evasion services, it is unclear how successful this form of reporting will turn out to be. Evaluating the effect of these recent policies is an important area for future research.
} 
Figure 10 shows the long-run evolution of the top $0.01 \%$ wealth share in Scandinavia, other European countries, and the United States. There are two notable findings. First, when including offshore assets, we find that Scandinavia and other European countries have experienced very similar trends in wealth concentration at the top over the twentieth century. Wealth concentration at the very top appears to have returned to its level of the 1950s, with a U-shaped evolution from the 1950s to today. Second, despite the more prevalent use of tax havens by Continental European countries, we find that wealth is much more concentrated in the United States. In fact, the top $0.01 \%$ wealth share in the U.S. is as high as in early 20 th century Europe.

\section{Conclusion}

In this paper we attempt to improve the measurement of wealth inequality by constructing new estimates of the amount of household wealth held offshore, and investigating the implications of offshore assets for top wealth shares. We make two main contributions. First, drawing on newly released statistics on cross-border bank deposits, we provide country-by-country estimates of the amount of offshore wealth owned by each of the world's country. The equivalent of about $10 \%$ of world GDP is held offshore globally, but this average masks a great deal of heterogeneity - from a few percent of GDP in Scandinavia, to about 15\% in Continental Europe, and more than 50\% in Russia, some Latin American countries, and Gulf countries.

Second, we investigate the implication of this hidden wealth for top wealth shares in a sample of 10 economies for which comparable wealth inequality statistics exist. Accounting for offshore assets increases the level and the rise of top wealth shares seen in tax data, but the magnitude of the effect varies across countries. Offshore wealth has particularly dramatic implications for the Russian wealth distribution, where, by our estimates, around $60 \%$ of the wealth of the richest households is held offshore. More broadly, offshore wealth is likely to have major implications for the concentration of wealth in many of the world's developing countries, hence for the world distribution of income and wealth, which is the subject of growing interest (e.g., Lakner and Milanovic, 2013).

Looking forward, we hope to systematize our approach to more countries, as new estimates of wealth distributions become available for more economies. Our estimates could also be refined as new data emerges on the level and distribution of offshore assets. Despite some progress in curbing bank secrecy in recent years, very little has been achieved in terms of statistical transparency. With the exception of Switzerland, no major financial center publishes 
comprehensive statistics on the amount of foreign wealth managed by its banks. Such opacity makes it hard to measure the evolution of global wealth and its distribution. Improving statistics on offshore wealth should be a priority for policy-makers in this area. 


\section{References}

Alstadsæter, Annette, Niels Johannesen, and Gabriel Zucman. 2017. "Tax Evasion and Inequality", NBER working paper, September.

Alvaredo, Facundo, Anthony Atkinson, and Salvatore Morelli. 2017. "Top Wealth Shares in the U.K. Over More than a Century," working paper.

Alvaredo, Facundo, Anthony Atkinson, Thomas Piketty, Emmanuel Saez, and Gabriel Zucman. 2017. The World Wealth and Income Database, http://WID.world.

Atkinson, Anthony B., and A. J. Harrison. 1978. The Distribution of Personal Wealth in Britain, Cambridge: Cambridge University Press.

Atkinson, Anthony, Thomas Piketty, and Emmanuel Saez. 2011. "Top Incomes in the Long-Run of History," Journal of Economic Literature, 49(1), 3-71.

Andersen, Jørgen Juel, David Dreyer Lassen, Niels Johannesen, and Elena Paltseva. 2016. "?Petro Rents, Political Institutions and Hidden Wealth: Evidence from Offshore Bank Accounts? Journal of the European Economic Association, forthcoming

Boston Consulting Group. 2008. "Global Wealth Report: A Wealth of Opportunities in Turbulent Times," September 2008.

Boyce, James K. 1992. "The Revolving Door? External Debt and Capital Flight: A Philippine Case Study," World Development, 20(3), 335-49.

Cap Gemini and Merrill Lynch. 2002. "World Wealth Report".

Čihák, Martin, Asli Demirgüç-Kunt, Erik Feyen, and Ross Levine. 2012. "Benchmarking Financial Systems around the World," World Bank Policy Research working paper \#6175.

Claessens, S., and D. Naudé. 1993. "Recent Estimates of Capital Flight." World Policy Research Working Paper \#1186.

Garbinti, Bertrand, Jonathan Goupille-Lebret, and Thomas Piketty. 2017. "Accounting for Wealth Inequality Dynamics: Methods, Estimates and Simulations for France (1800-2014)," working paper.

Harrington, Brooke. 2016. Capital Without Borders, Cambridge: Harvard University Press. Henry, James S. 2012. "The Price of Offshore Revisited: New Estimates for Missing Global Private Wealth, Income, Inequality, and Lost Taxes", Tax Justice Network working paper.

Johannesen, Niels. 2014. "Tax Evasion and Swiss Bank Deposits," Journal of Public Economics, 111, 46-62.

Johannesen, Niels, and Jukka Pirttilä. 2016. "Capital flight and development: An overview of concepts, methods, and data sources," WIDER working paper 2016/95.

Johannesen, Niels, and Gabriel Zucman. 2014. "The End of Bank Secrecy? An Evaluation of the G20 Tax Haven Crackdown," American Economic Journal: Economic Policy, 6(1), 65-91. Kuznets, Simon. 1953. Shares of Upper Income Groups in Income and Savings, New York: National Bureau of Economic Research.

Lampman, Robert J. 1962. The Share of Top Wealth-Holders in National Wealth, 1922-56, Princeton, NJ: Princeton University Press.

Lakner, Christoph and Branko Milanovic. 2013. "Global Income Distribution: From the Fall of the Berlin Wall to the Great Recession." World Bank Policy Research Working Paper. 
Larudee, Mehrene. 2016. "Did capital go away? Capital flight as an explanation for declining reported wealth inequality during and after World War I," mimeo, University of Massachusetts. Lensink, R., N. Hermes, and V. Murinde. 2000. "Capital Flight and Political Risk." Journal of International Money and Finance, 19(1): 73-92.

Martínez-Toledano, Clara. 2017. "Housing Bubbles, Offshore Assets and Wealth Inequality in Spain", working paper.

Novokmet, Filip, Thomas Piketty and Gabriel Zucman. 2017. "From Soviets to Oligarchs: Inequality and Property in Russia, 1905-2016," NBER Working Paper No. 23712.

Omartian, Jim. 2017. "Tax Information Exchange and Offshore Entities: Evidence from the Panama Papers," working paper.

Owens, Jeffrey. 2007. "Offshore Tax Evasion: The Role of Exchange of Information," written testimony before the Senate Finance Committee on Offshore Tax evasion, May 3, 2007.

Palan, Ronen, Richard Murphy, and Christian Chavagneux. 2010. Tax Havens: How Globalization Really Works, Cornell Studies in Money, Ithaca, NY: Cornell University Press.

Pastor, M. 1990. "Capital Flight from Latin America". World Development, 18(1), 1-18.

Pellegrini, Valeria, Alessandra Sanelli, and Enrico Tosti . 2016. "What do External Statistics tell us About Undeclared Assets held Abroad and Tax Evasion?," Bank of Italy Occasional Paper 367.

Piketty, Thomas. 2014. Capital in the 21st Century. Cambridge: Harvard University Press. Piketty, Thomas, and Emmanuel Saez. 2003. "Income Inequality in the United States, 1913-1998," Quarterly Journal of Economics, 118(1), 1-39.

Piketty, Thomas, and Gabriel Zucman. 2014. "Capital is Back: Wealth-Income Ratios in Rich Countries, 1700-2010," Quarterly Journal of Economics, 129(3), 1255-1310.

Piketty, Thomas, Emmanuel Saez, and Gabriel Zucman. 2016. "Distributional National Accounts: Methods and Estimates for the United States, 1913-2013," NBER Working Paper.

Roine, Jesper, and Daniel Waldenström. 2015. "Long-run Trends in the Distribution of Income and Wealth." In Handbook of Income Distribution. Vol. 2, ed. Anthony B. Atkinson and Francois Bourguignon, Chapter 7, 469-592. Elsevier/North Holland.

Roussille, Nina. 2015. "Tax Evasion and the 'Swiss Cheese' Regulation," mimeo.

Saez, Emmanuel and Gabriel Zucman. 2016. "Wealth Inequality in the United States since 1913: Evidence from Capitalized Income Tax Data," Quarterly Journal of Economics., $131(2), 519-578$.

UNDP. 2011. "Illicit Financial Flows from the Least Developed Countries: 1990-2008". Discussion Paper.

U.S. Senate. 2008. "Tax Haven Banks and U.S. Tax compliance." Staff Report of the Permanent Subcommittee on investigations. Washington, DC, July.

U.S. Senate. 2014. "Offshore Tax Evasion: The Effort to Collect Unpaid Taxes on Billions in Hidden Offshore Accounts." Staff Report of the Permanent Subcommittee on investigations. Washington, DC, February.

Zucman, Gabriel. 2013. "The Missing Wealth of Nations: Are Europe and the US net Debtors or net Creditors?" Quarterly Journal of Economics, 128(3), 1321-1364.

Zucman, Gabriel. 2014. "Tax Evasion on Offshore Profits and Wealth," Journal of Economic Perspectives, 28(4), 121-148. 
Zucman, Gabriel. 2015. The Hidden Wealth of Nations: The Scourge of Tax Havens, Chicago: University of Chicago Press. 


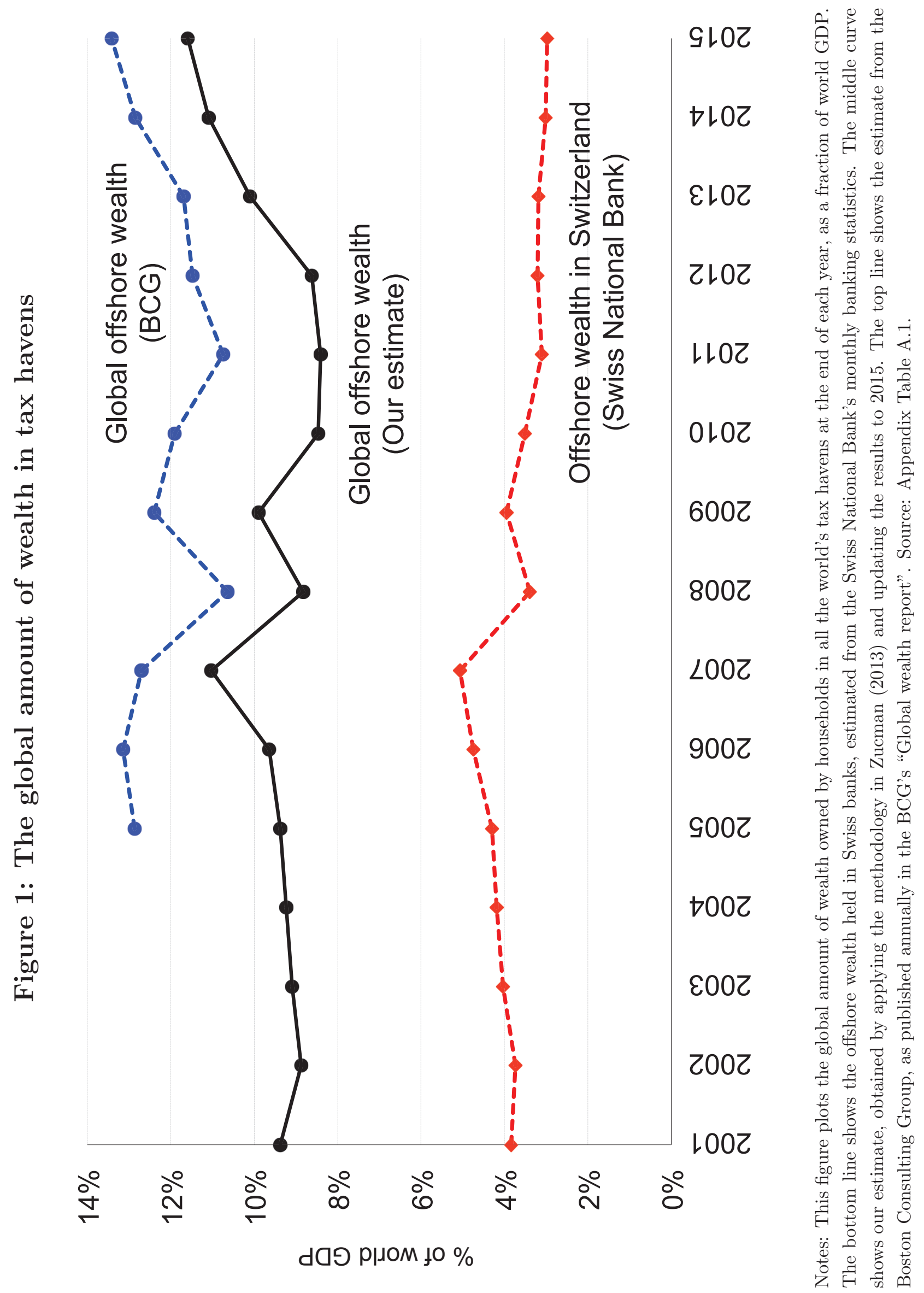




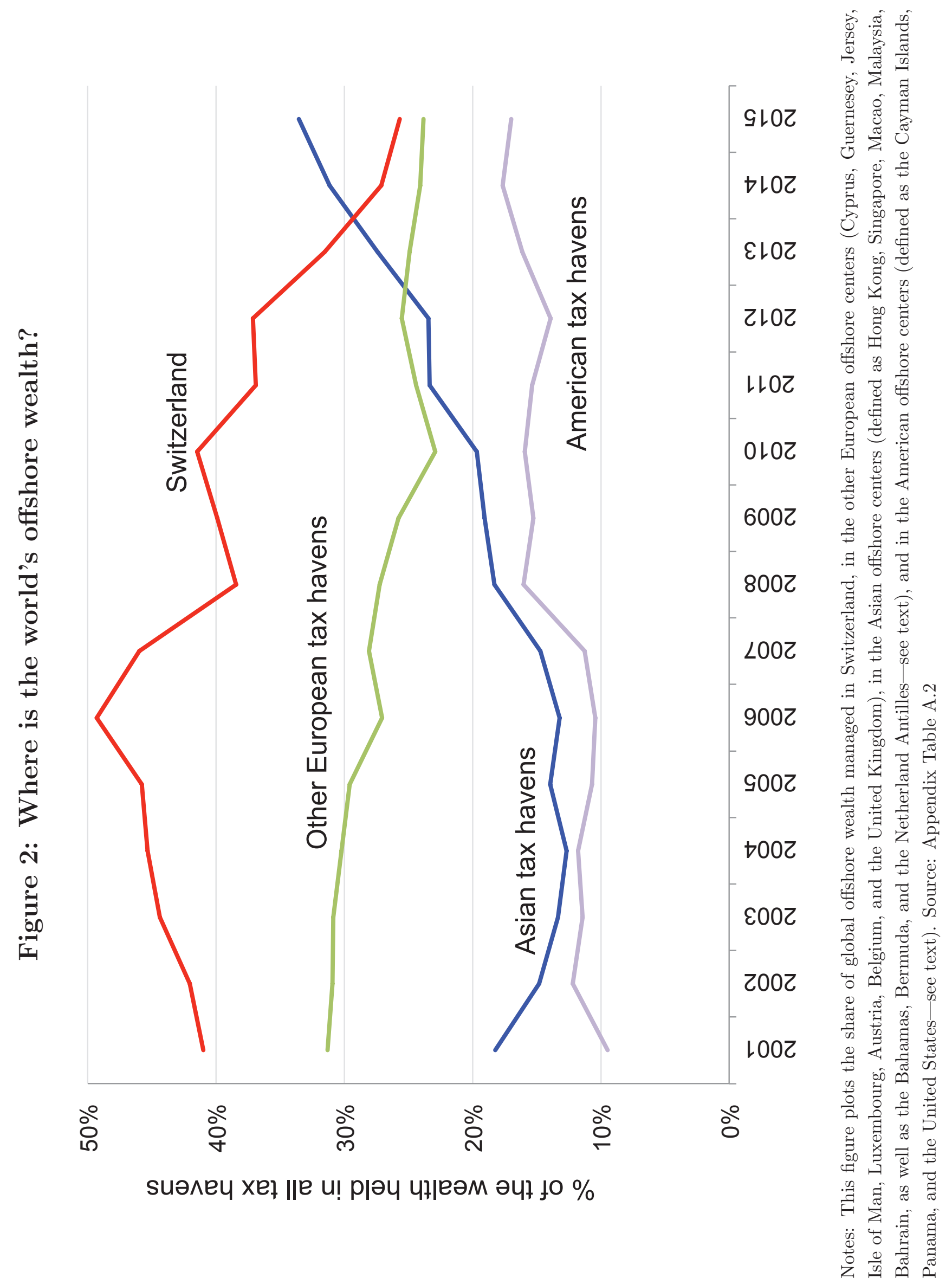




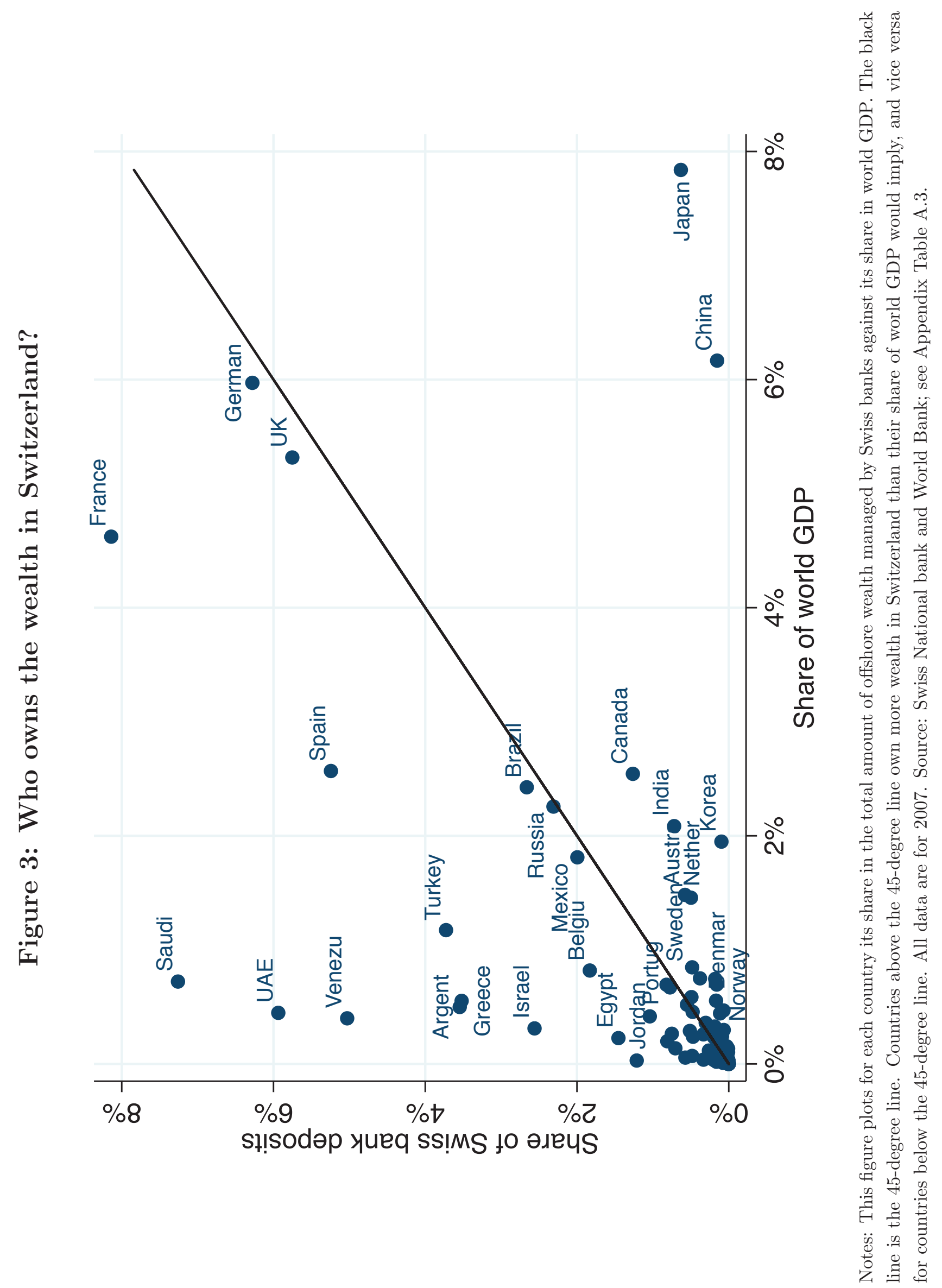




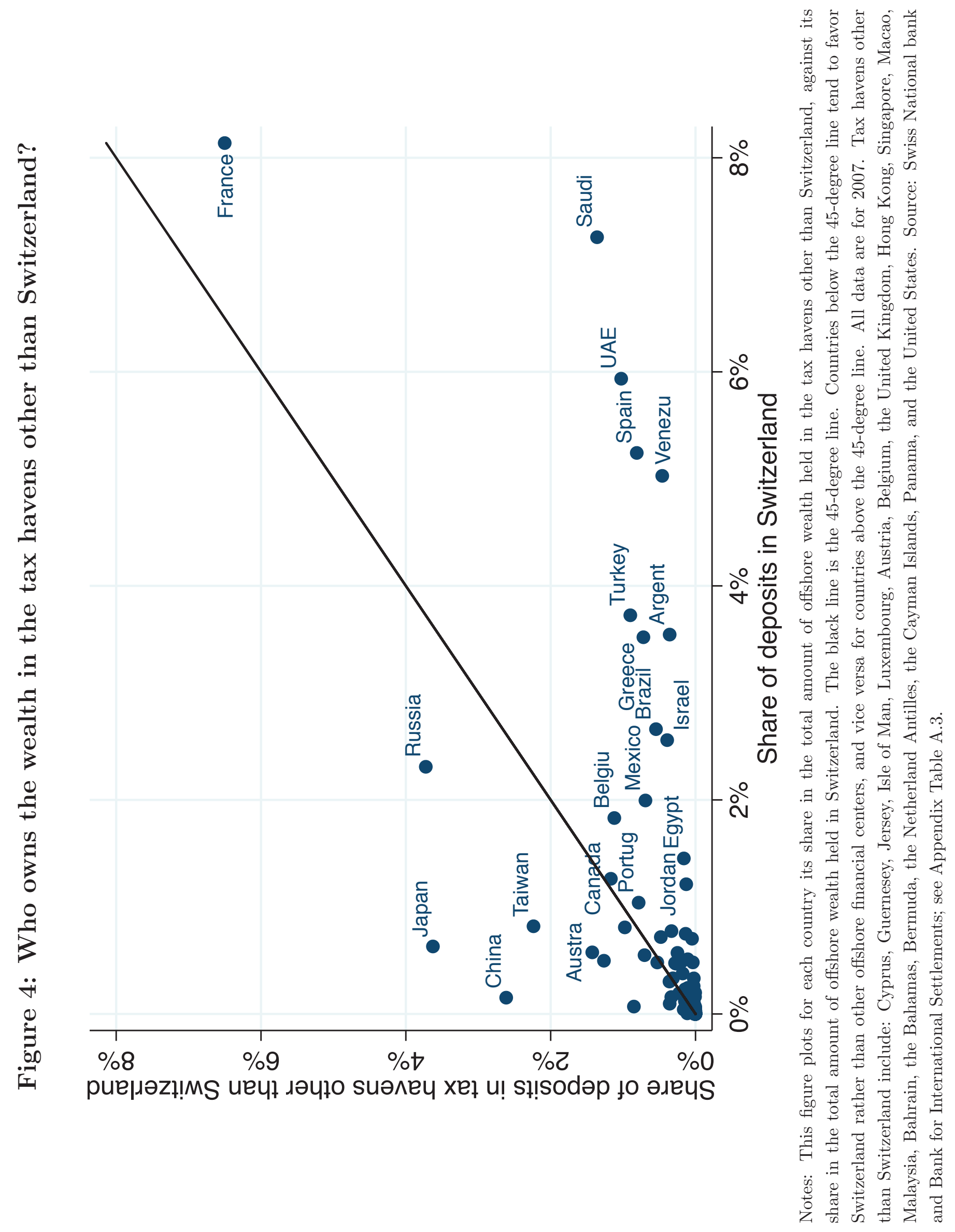




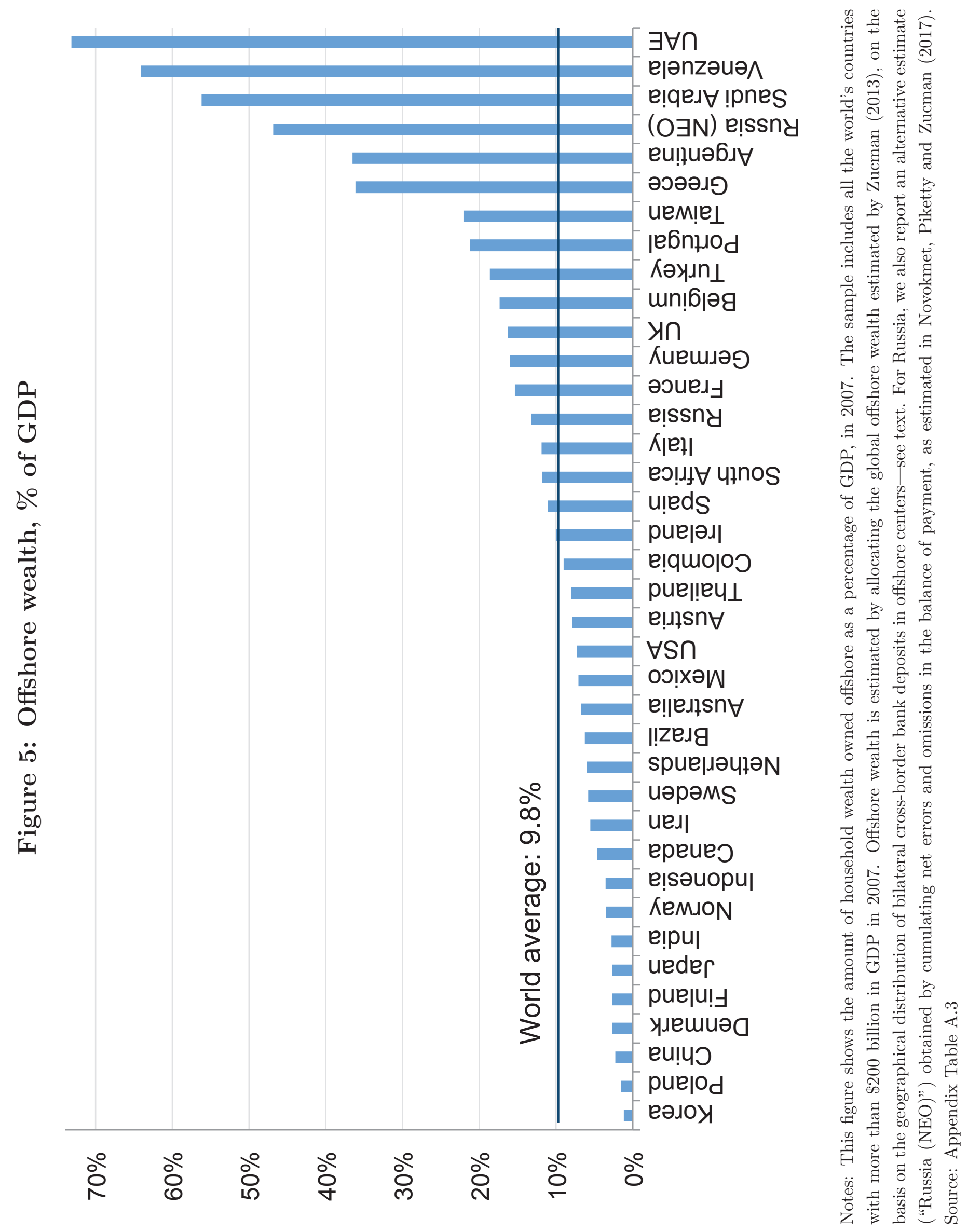




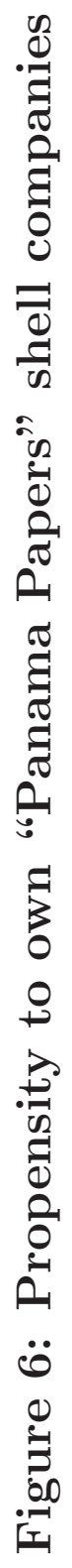

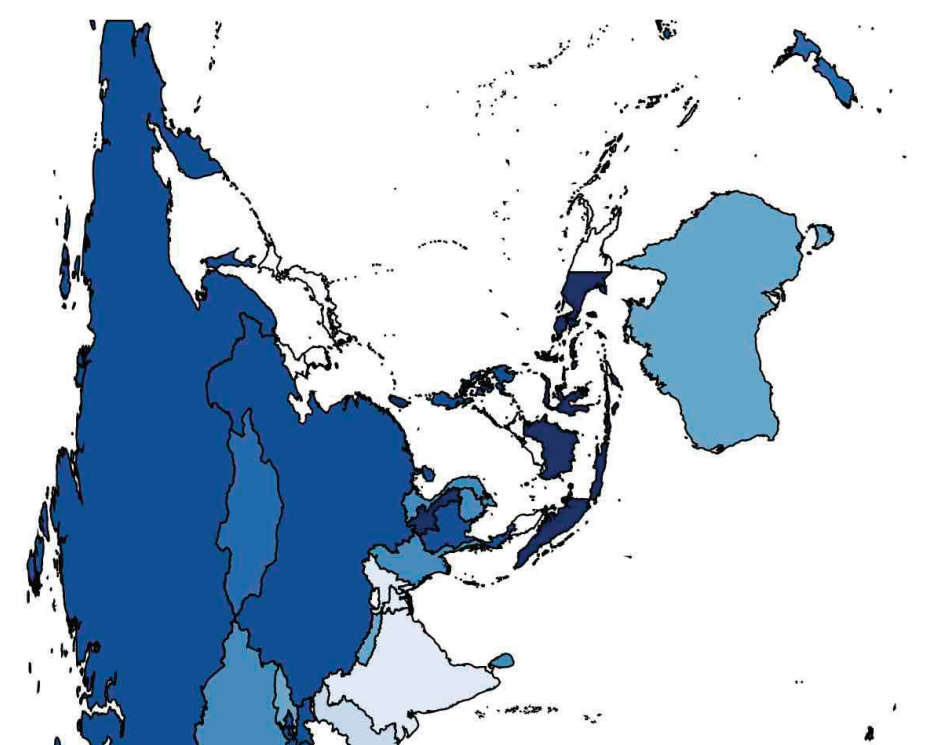

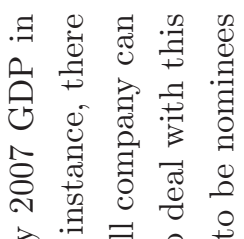

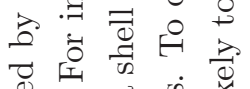

灵灾

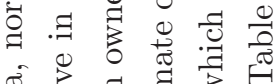

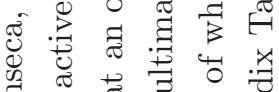

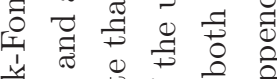

प्र

永

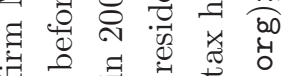

สี

范

สี

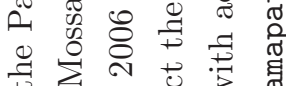

bे

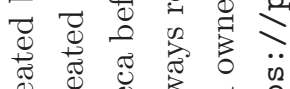
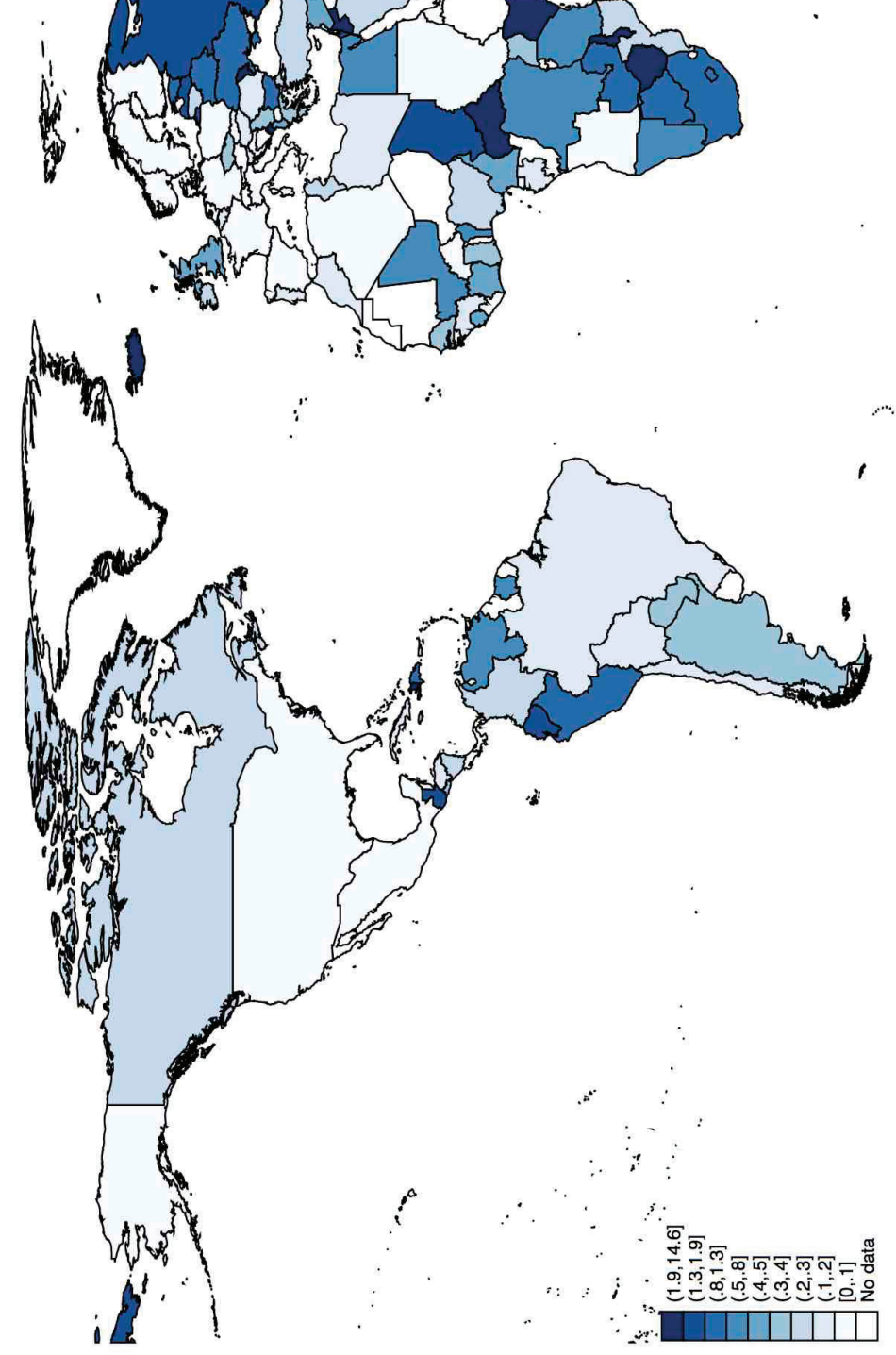

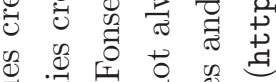

藏藏

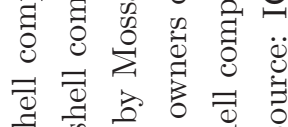

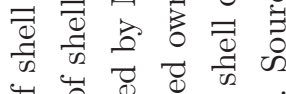

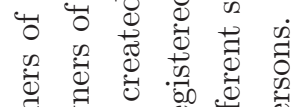

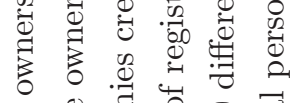

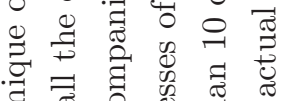

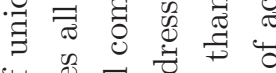

पै

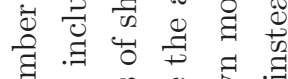

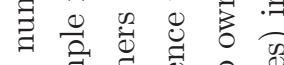

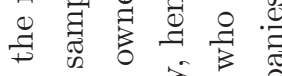

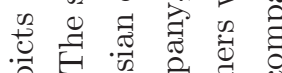

की

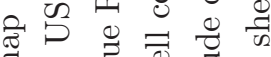

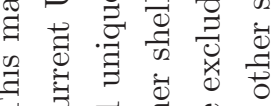

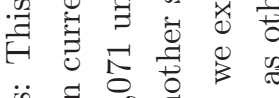

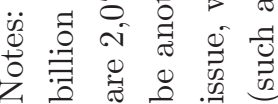




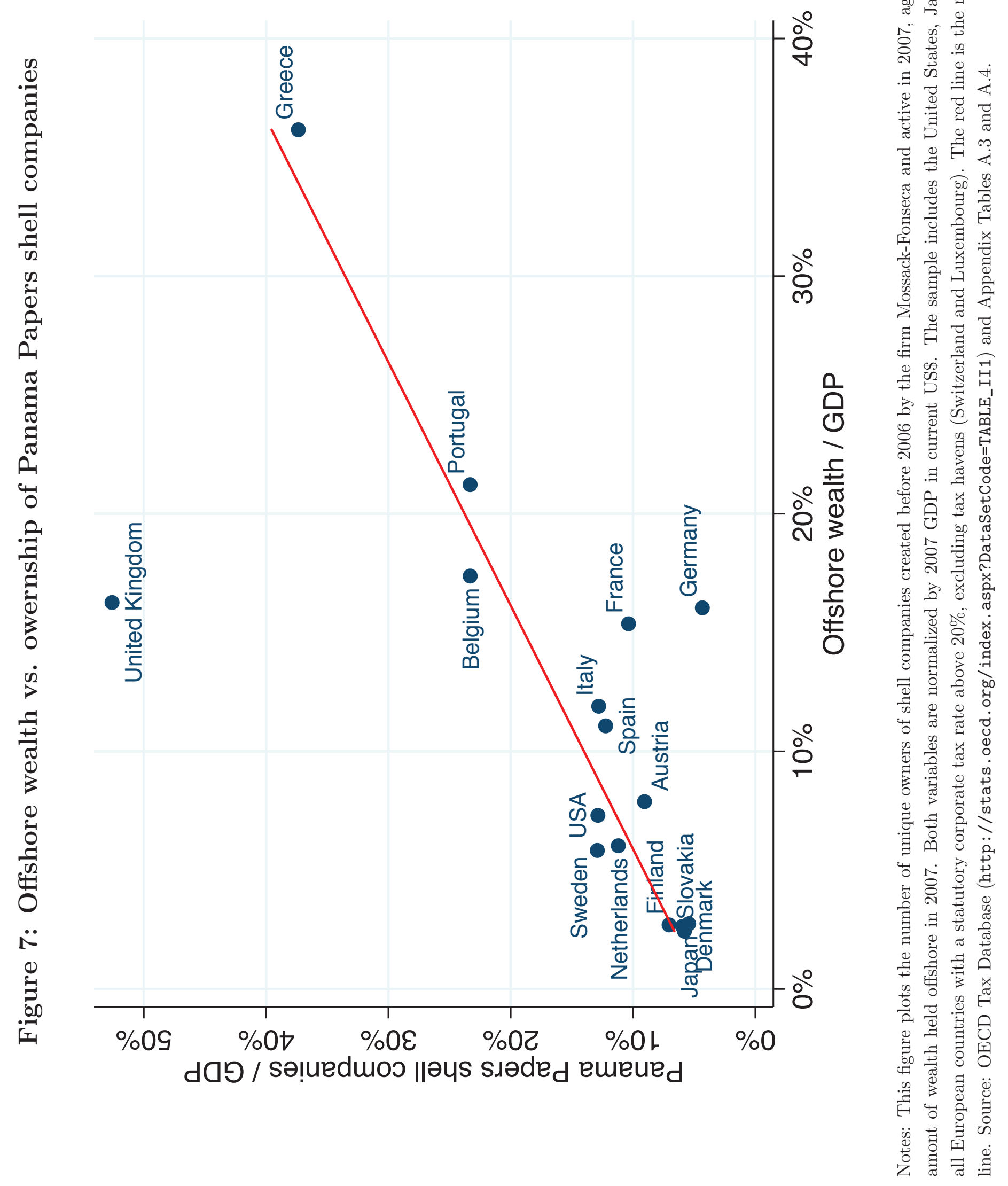




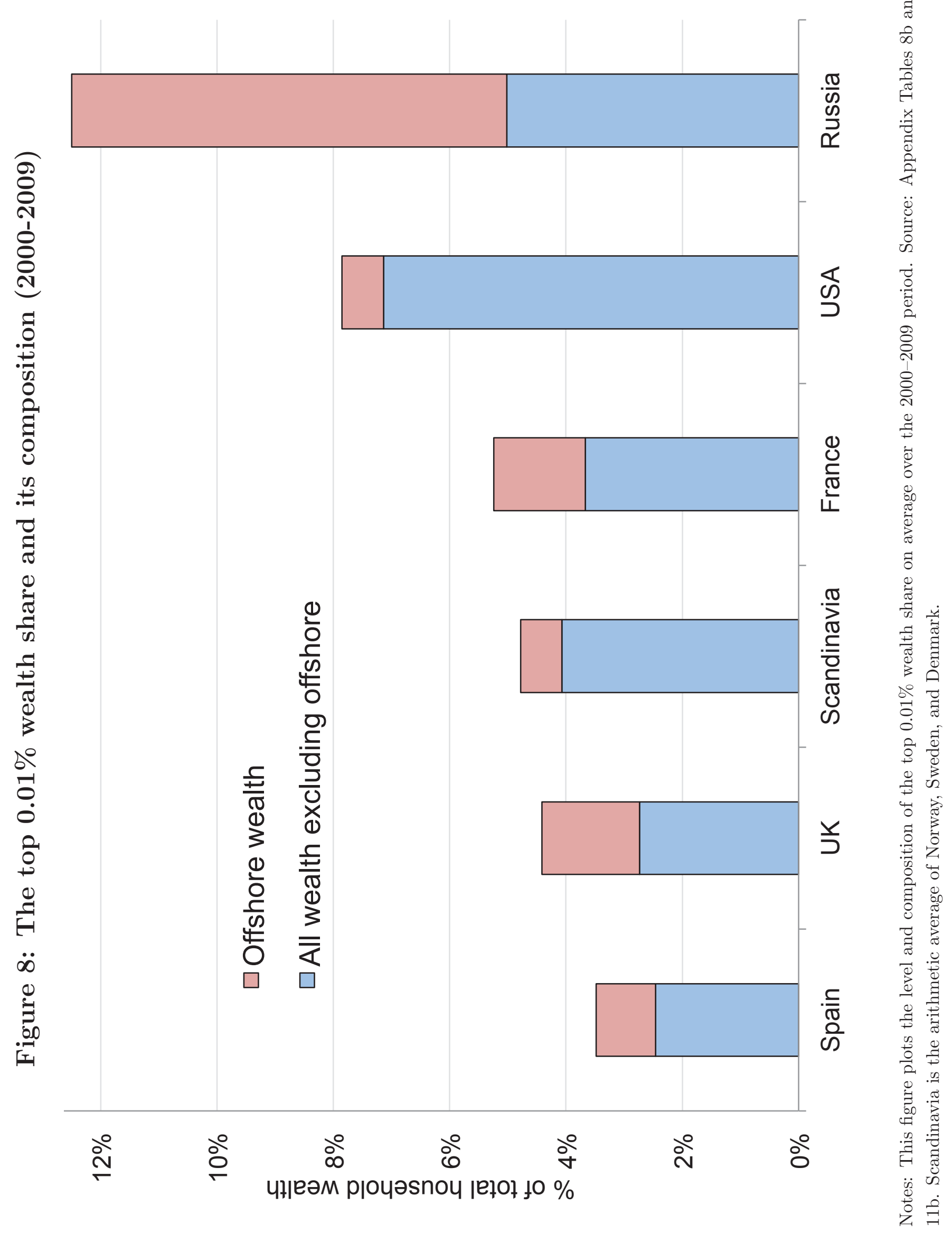




\section{Figure 9: Effect of offshore wealth on the dynamic of the top $0.01 \%$}

Panel A: Top 0.01\% wealth share in France

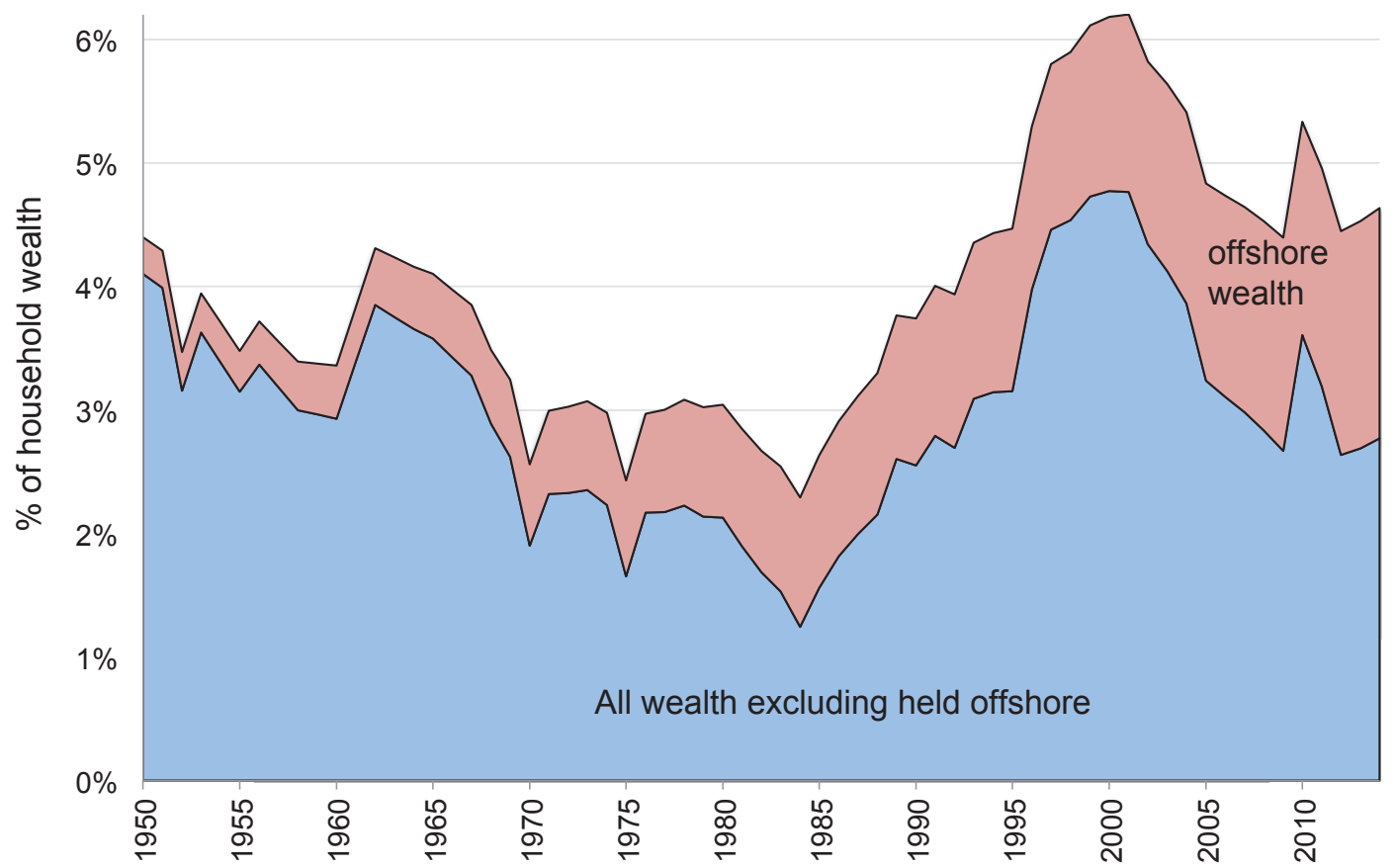

Panel B: Top $0.01 \%$ wealth share in the United Kingdom

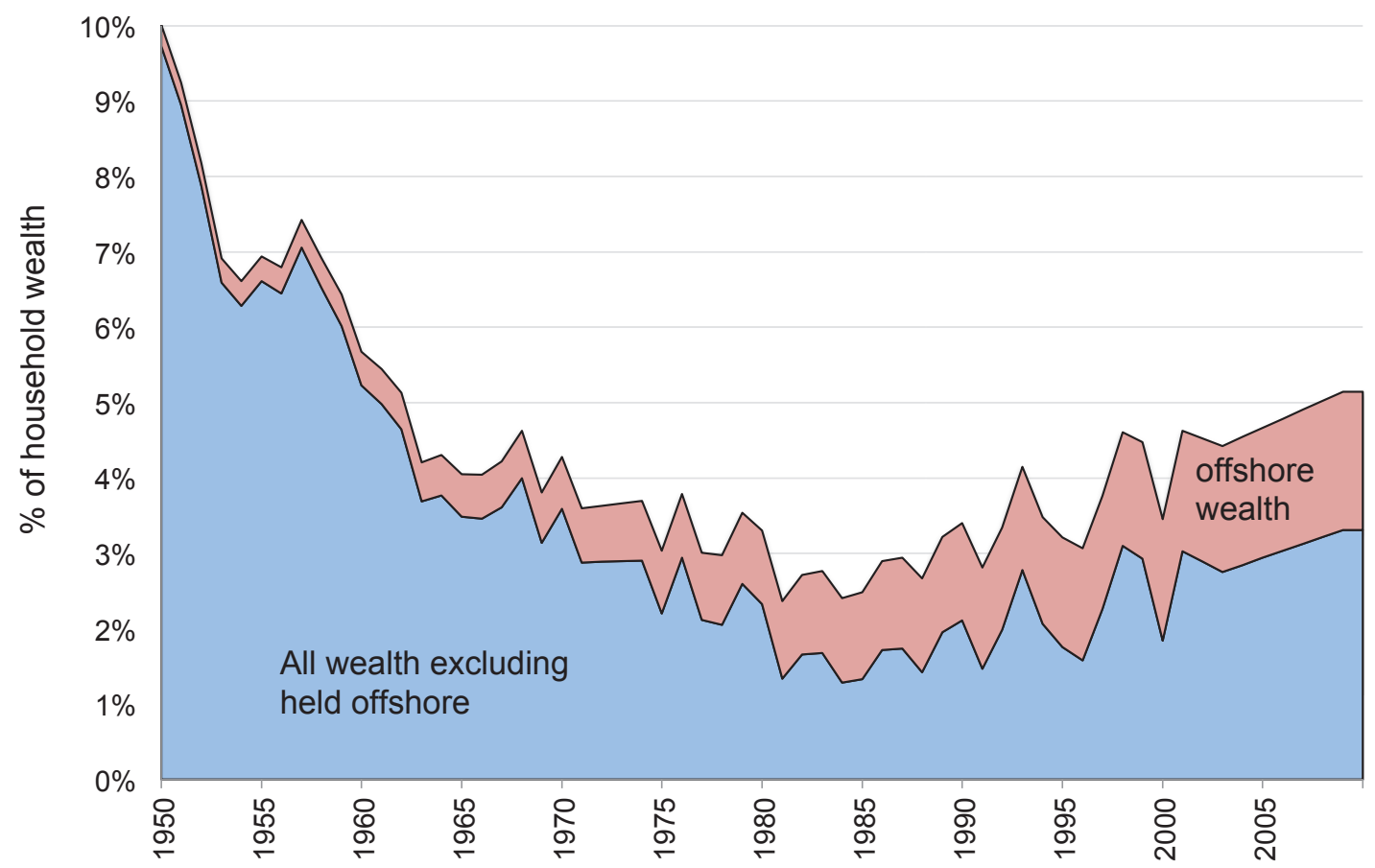

Notes: This graph shows the evolution and the composition of the top $0.01 \%$ wealth share in France (top panel) and the U.K. (bottom panel), isolating offshore wealth and all other assets (financial and non-financial, net of debts). Source: Appendix Table A.11. 


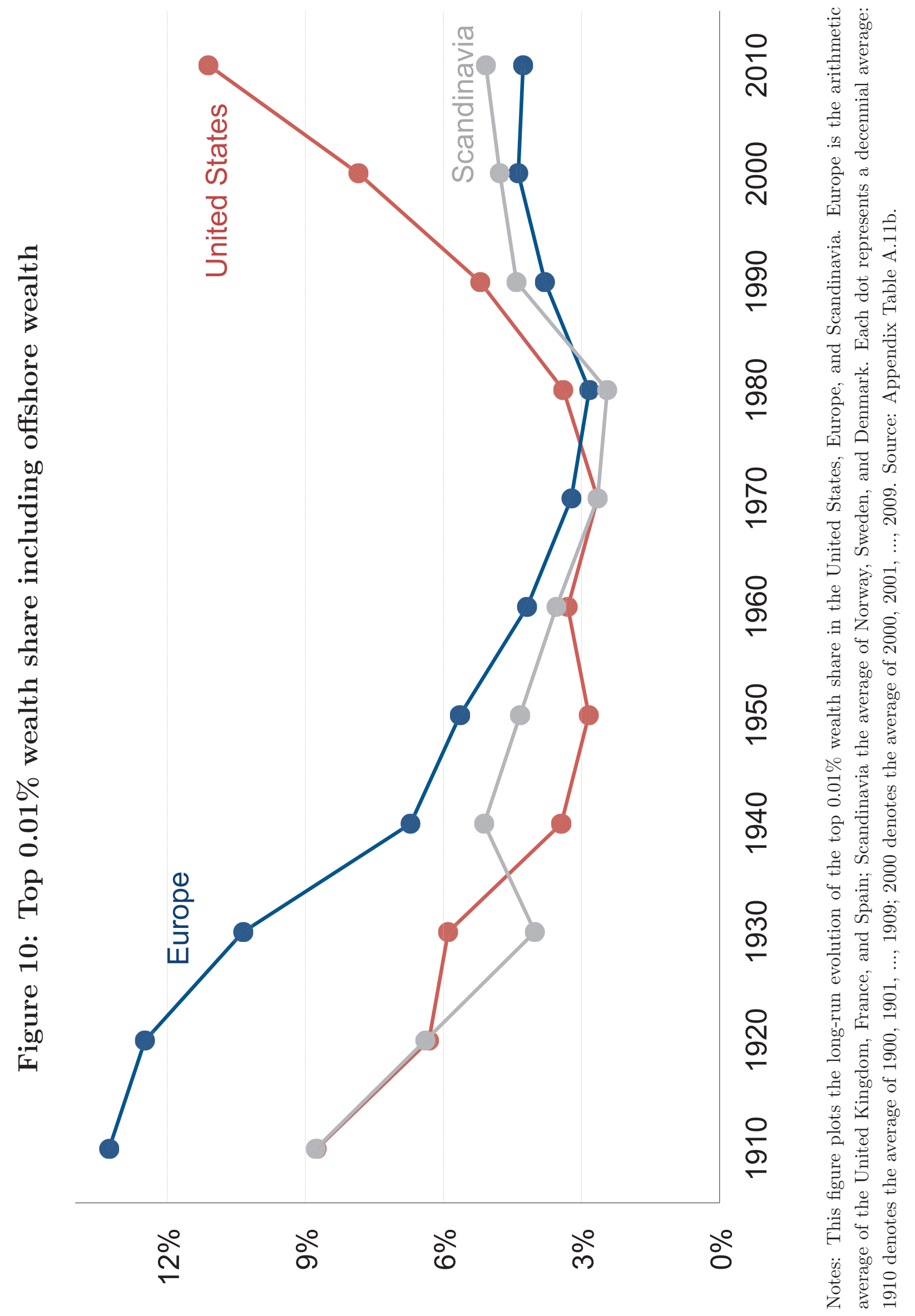

